\title{
Challenge of Advocate's Profession in the Age of Money Laundering, Terrorism Financing and Proliferation Evasion "Not to slip with a fragile burden!"
}

\author{
Sandra Joksta \\ Joint Stock Company "Latvijas Gāze”, Latvia \\ sandra.joksta@lg.lv
}

\section{Abstract}

Ability to perform advocate's duty is irrevocably linked to advocate's immunity concept. The article provides an insight about the scope of advocate's immunity concept in the age of money laundering. The purpose of it is to analyse the modern tendency to overstep the red lines guarding this concept, when applying legal enactments for money laundering evasion purposes. In the article, the judgment of 19 November 2020 in case "Klaus Mueller vs Germany" made by European Court of Human Rights, is analysed, where the issue of advocate's immunity was considered in joint connection with the Clause 8 of the Convention for the Protection of Human Rights and Fundamental Freedoms.

The sometimes-exaggerated need for transparency at all costs conflicts with privacy protection aspects of individuals. Legislative enactments of money laundering and terrorism financing and proliferation evasion systemically contradicts Law of Advocacy and causes collision with other norms of higher legal rank such as fundamental rights enshrined in the European Convention on Human Rights to fair trial and justice and rights to choose an occupation and engage in work.

Keywords: advocate's immunity concept, advocate's rights to professional secret and confidentiality, legal certainty, money laundering and terrorism financing and proliferation evasion, principle of sound legislation, uncertain privilege.

\section{Introduction}

When moulding the title of this article, the author was inspired by writings of the Russian Empire's advocate Mr. Fyodor Plevako, namely, his assertions and reflections 
Sandra Joksta. Challenge of Advocate's Profession in the Age of Money Laundering,

Terrorism Financing and Proliferation Evasion "Not to slip with a fragile burden!"

about advocate's profession as the one with the highest standards in the legal profession and simultaneously as a tool by means of which fundamental human rights and freedoms are implemented in democratic society:

\footnotetext{
"Behind the prosecutor, there is a deaf, cold, and unshakable law, behind the defendant, there is a human being with his own destiny, wishes and needs; and this human being crawls onto the shoulders of its defender seeking protection; it is dangerous not to slip with such a burden on your shoulders!" (Plevako, 2017, 30)
}

This article is devoted to analysis of advocate's immunity concept (aspects of professional secret and confidentiality) in the age of money laundering. Throughout the article, the author will try to identify where the red lines that sketch advocate's immunity concept in the money laundering field are and whether they are not being overstepped, putting the fundamental rights and democratic values of society at risk. This has been researched from the point of view of implementation of society's fundamental rights i.e. rights of defence and rights to fair trial.

The recent judgement made by the European Court of Human Rights (hereinafter - ECHT) on 19 November 2020 in the case "Klaus Mueller vs Germany" (application No. 24173/18) considered the issue of advocate's immunity in joint connection with the Convention for the Protection of Human Rights and Fundamental Freedoms (The Convention for the Protection of Human Rights and Fundamental Freedoms, 1997, Article 8). The importance of this judgement lies in the fact that currently the issue of combating money laundering and the financing of terrorism and proliferation and the related enforcement and problems in Latvia has been recognised as the top priority of the country, and it prevails over the issue of advocate's immunity. Moreover, it is important to note that transparency often opposes the human rights in respect of privacy protection aspects, which, in their turn, are one of the fundamental rights, protected by the European Convention on Human Rights.

The value of the judgement also lies in the fact that it reflects diverging views of the courts upon this question. There is no unified approach and evaluation yet established within the Court level. The situation is similar in Latvia. The Courts have not adopted unified interpretation of the situation where the norms protecting human rights and fundamental freedoms are opposed to the need for maximum transparency exposure in Anti-Money Laundering (hereinafter - AML) sector, i.e., to make transparency at all costs.

The purpose of the article is to inform the reader about the substance of the matter, the ECHT arguments and conclusions, and express the author's own assumptions about its importance for Latvia in the context of Anti Money Laundering and Finance of Terrorism (hereinafter - AMLFTP) regulations (The law on combating money laundering and the financing of terrorism and proliferation, 2008) and development of legal thinking. 
Sandra Joksta. Challenge of Advocate's Profession in the Age of Money Laundering,

Terrorism Financing and Proliferation Evasion "Not to slip with a fragile burden!"

\section{The Basis}

The applicant submitting a complaint was a sworn advocate who during the period from 1996 to 2014 had provided legal services to four entrepreneurs in connection with various transactions. In 2017 criminal proceedings were initiated against these entrepreneurs in relation to the activities of persons in charge of these companies, including possible fraud.

Within the respective criminal proceedings before the Court of Appeal, the advocate was summoned as a witness to testify about the transactions of enterprises. Insolvency administrators of the companies agreed that the applicant would be released from professional secrecy. However, during the court session, based on the rights stipulated in the criminal code, the applicant refused to testify, because the information had been obtained during performance of his professional duties as an advocate providing legal advice to his client. The applicant considered that it is also necessary to obtain permission of former persons in charge of the enterprises, who were the managing directors during the time when the applicant provided his legal services. However, the court disagreed with the applicant's opinion and acknowledged that it is sufficient to have consent of the current representatives of companies by adjudging administrative penalty to the applicant for unjustified refusal to witness.

By using all appealing options available and considering that the rights mentioned in Article 8 of the European Convention on Human Rights and the Charter of Fundamental Rights of the European Union - freedom to privacy and immunity of family life, the applicant brought a claim to the ECHT. In the claim, he noted that the offence, which was placement of administrative penalty, which might be followed also by imprisonment for refusal to witness, violates the applicant's right to privacy and correspondence in accordance with Article 8 of the European Convention on Human Rights and the Charter of Fundamental Rights of the European Union. Moreover, such a decision about issuance of administrative penalty is contrary to the rights enlisted about a possible refusal to testify if the information had been obtained during performance of professional duties. It has also been stated that in the given case it is not material that the applicant (his office) had signed the agreement on provision of legal services solely with enterprises as corporate persons because the relationship based on trust can similarly be established only with private persons. In the given case, the applicant was forced to testify in criminal proceedings about the facts that had become known to him during provision of legal services. The applicant also indicated that in the German court practice there are different opinions and a case-law regarding the issue whether in case of companies' managing directors it is necessary also to hold a permission from former managing directors to provide testimonies by relieving the advocate from the duty of confidentiality.

The ECHT in the given case did not note a violation of the rights according to Clause 8 of the European Convention for the Protection Human Rights and Fundamental 
Sandra Joksta. Challenge of Advocate's Profession in the Age of Money Laundering,

Terrorism Financing and Proliferation Evasion "Not to slip with a fragile burden!"

Freedoms. The court concluded that the applicant had a reasonable basis to consider that national courts admit it as sufficient to obtain a permission from the existing management of companies for the advocate to provide evidence about the provided legal advice. In fact, the ECHT agreed that the information obtained during performance of professional duties should be protected, but, if, according to the national rights, it is sufficient to have consent of existing companies' management for disclosure of this information, the advocate is not anymore entitled to provide evidence about contents of legal assistance. (Latvian Sworn Advocates Council, 2020).

\section{Analysis of Substantial Assumptions of the Judgment}

Under the effective legislation in the Republic of Latvia with respect to advocate's professional activities - "sworn advocate may not divulge the secrets of his or her authorising person not only while conducting the case, but also after being relieved from the conducting of the case or after the completion of the case" (The Advocacy Law of the Republic of Latvia, 1993, Article 67). The existing regulation does not provide a possibility to deviate from the assumption; if a clear consent is not received from the client to be released from the duty to keep business secret and not to disclose data, which the advocate has obtained from the client while providing legal advice to the latter, the duty of confidentiality remains in force. The tendency of the assumptions adjudged by the ECHT judgment indicate that advocate's immunity issue is not a constant and fixed legal notion; instead, it can be widely interpreted and discussed, and applied. The ECHT also holds no full equal opinion about the issue in the context of the mentioned judgment. One of the judges, judge Ms. Judkovska, objected against such ECHT opinion and expressed it in a written argumented opinion. In her opinion, she, inter alia, indicated to the unclear [advocate's] privilege aspect and analysed interruption, which has been supported by necessary measures for a democratic society as a measure for reasonableness of such interruption. In this respect she referred to the judgement made by the US Supreme Court in the case of Upjohn Company by analysing the notion of unclear privilege (US Supreme Court, 1981):

\footnotetext{
"If a service is rendered and received under a mutual agreement between the attorney at law and the client, then the attorney at law and the client should be able to predict with a certain degree of legitimate expectation whether the given conversations will be protected. Uncertain privilege, or the one that only seems to be certain, but is interpreted and applied by the courts differently, is no better than a non-existent privilege."
}

Judkovska emphasised that in this situation the interests of a private person and the interests of a person as a company's director cannot be separated because the company cannot itself hire an advocate and provide information to them. There is always a duly authorised person who secures the exchange of information in the meantime expressing his opinion and will. Consequently, such type of communication, performed 
Sandra Joksta. Challenge of Advocate's Profession in the Age of Money Laundering,

Terrorism Financing and Proliferation Evasion "Not to slip with a fragile burden!"

between the advocate who is providing professional legal services to the company, and the managing director or authorised representative of the company who is always a private person, is undoubtfully subject to assumptions about advocate's immunity and privilege. By applying a penalty on the advocate for refusing to witness upon absence of consent, which is clearly stated in law, from other three company's managers, the authorities have violated the principle of proportionality during the review of the case and violated Article 8 of the European Convention on Human Rights and the Charter of Fundamental Rights of the European Union.

Legislative regulations of Republic of Latvia (The Advocacy Law of the Republic of Latvia, 1993, Article 6, Paragraph 6) also prohibit to subject an advocate to any sanctions or threats in connection with provision of legal assistance according to the law. However, by the said ECHT judgment, advocate is forced to refuse from their inherent rights to professional secret and confidentiality and rights to engage in work and limit advocate's immunity.

The lawyer and legal philosopher R. Alexy reflects on the dual nature of law, describing and investigating the problem of need for balance between ideal and real dimensions in the field of law, to arrive at the state of ideal democracy, explaining the components of this process:

"Law has a dual nature. [..] The thesis about the dual nature brings an assumption that the law comprises both the real or actual dimension, as well as the ideal or critical dimension. In the definition of law, the actual dimension is represented by the consideration of the society and the authority's ability to make assessments and ensure competence, whereas the ideal dimension is manifested in the element of moral correctness." (Alexy, 2010, 167)

"The dual nature of law requires that these both sides would be in correct proportion against each other. To the level, in which this proportion is reached, the harmony of legal system is ensured." (Alexy, 2010, p.174).

Anti-money laundering legislative framework is very radical and strict, and noncompromisory as it tries to identify and eliminate threats to the fundamental freedoms caused by terrorism, proliferation and money laundering activities. In many cases it is being implemented by means of restricting and limiting other rights or interests, including the fundamental rights of advocates to professional secrecy, or limiting the fundamental principles of legal certainty and principle of justice thus threatening or weakening the democratic values as set by the Constitution in general.

Article 8 of the European Convention on Human Rights confers additional protection to advocate-client relationships. Additional protection is justified by advocate's fundamental role in the society. In case advocates are not able to guarantee the confidentiality of their clients, they are not able to perform their duty. The relationship of trust between advocate and client is a precondition to be able to provide and receive legal services and that, in turn, secures fundamental rights of a person to a fair trial, including the right of accused persons not to incriminate themselves. 
In 1998, the new wording of the Charter of Fundamental Rights of the European Union entered into force and the European Court of Human Rights admitted that legal professional privilege is a fundamental right which can be violated or limited only in exceptional cases.

There exist discussions amongst the professionals of the field that with the legislative AML requirement to report suspicious activity or transaction of the client, the principle of professional secrecy of the lawyer is weakened and threatened. This consideration is grounded by additional protection stated by this norm. Moreover, the position is accurate if looked upon from ideal or moral dimension of law. Nonetheless, the real dimension, i.e., the reason why the AML legislation and idea and concept were developed must be faced. Namely that the problematic of AML is a threat to the interests of society and security, and this can be equalled to the threatening of fundamental rights. There can be no objections towards such position as well. The threats are realistic. Both positions are of highest possible legal rank; they directly impact the fundamental rights, and both are equal in their strength from the validity point of view. Therefore, balancing among these is strongly required as it is not possible to respect each entirely, part of it must be donated in favour to the other right in order to reach and maintain the required balance.

The main and most important task for the legislator during the implementation and enforcement of legal regulations with a new legislative enactment, idea or principle and legal norms in practice is to strive for finding the balance of law. Legislator should understand these theoretical presumptions of dimensions of law and try to find ways how to reconcile and approximate these two dual natures to achieve the ideal balance of law.

\section{Advocate's Privilege or Fundamental Rights to Professional Secret and Confidentiality}

According to Article 3 of the Advocacy Law of the Republic of Latvia, advocate is an independent and professional lawyer who provides legal assistance by defending and representing the lawful interests of persons in the court and in pre-court investigation.

The Advocacy Law of the Republic of Latvia regulates advocates' professional activities. Advocacy is an integral part of a judicial system in a law-governed state. In their profession, the advocate is independent and subject only to the Law of advocacy. State and municipal authorities and courts, prosecutors and pre-court investigation establishments should guarantee their independence.

In 2008, with the introduction of AMLFTP law, the scope of legal entities of said law was widened and new norms and duties were envisaged also for advocates, such as to carry out and document money laundering and terrorism financing and proliferation evasion risk assessment in order to clarify, evaluate, understand and monitor the risks attributable to operations of his client and the area of client's operations, based on the selfmade assessment - establish internal control system by drawing up and documenting respective policies and procedures. 
It is important to regard the aspects of advocate's professional secret and confidentiality within the context of fundamental rights of society (implementing rights to defence and justice).

A democratic society is based on two fundamental aspects - rule of law and rule of justice. The rule of law cannot exist without defence and without an advocate there is no defence. Defence is not imaginable without the client's rights to freely express his opinion and trust advocate at the same time having legitimate expectations that all the information disclosed will remain confidential.

It is significant to note that advocate's professional secret and confidentiality obligation (the Advocacy Law of the Republic of Latvia, 1993, Article 67) cannot be regarded as advocate's privilege. On the contrary, they are advocate's duty and obligation towards their client and have been introduced into the legal system exactly to serve the interests of an individual. In such way the rights of defence and serving society on the whole are guaranteed. At the same time, it should be noted clearly that this privilege must not be used for hiding illegal actions. If the advocate suggests or helps a client to make an illegitimate activity by being aware that it is illegal, the advocate is subject to disciplinary penalty and this privilege is not applicable to the situation. In this case this action cannot be treated as the advocates professional activity. The level of advocates knowledge, skills and ethics is determined by education and examination system and high ethical and moral standards of the profession.

\section{Scope of Immunity of Advocate and Collision with Existing Regulation}

The issue of advocate's immunity scope is interrelated with the understanding of the function or role of advocate as a tool in ensuring fundamental rights of defence in society and realisation of justice in the court on one part and the principle of proportionality by comprising its integral elements - need, necessity, and compliance - on the other part.

There is no dispute about the fact that intervention by means of legal regulation in respect to advocate's immunity scope cannot be discussed in respect of a situation when the advocate, by using its operational privileges or advocate's immunity, acts dishonestly in his own interests. The Law of Advocacy of the Republic of Latvia clearly states that in these cases the issue of advocate's immunity is not under discussion because it refers solely to the activities of an advocate. Whereas an intentionally dishonest action which leads or might lead to committing a criminal offence, may not be treated as the advocate's activity

In the present article, an ordinary established situation has been analysed - where the advocate honestly performs his professional duties. In 2008, upon introduction of amendments to AMLFTP Law, the scope of subjects of the Law was increased and the advocate was automatically included to be the subject of the Law due to their inherent 
nature of being a "gatekeeper" in the context of AMLFTP. Irrespective the fact that the mentioned law was developed initially for the financial sector, it got automatically expanded without evaluating the possibilities of this new range of subjects to really be able to carry out the assessment required by the law according to the requirements of Law as well as the significance of their role as "gatekeepers" according to the sector's statistics. Instead, additional burden of duties was determined when providing services, which sometimes are impossible to perform due to lack of access to information, for example, when interpreting information in the scope provided in the Law in respect of true beneficiaries (hereinafter - beneficiaries), politically significant persons, the vast formulation about risky territories from AMLFTP viewpoint, also in respect to resources - both regarding the requirement of due diligence research of the client and an obligation to report each and any suspicious transaction.

For the purposes of substantiating the above assumption, it is valid to refer to the term of suspicious transaction defined in AMLFTP law - it is a transaction or activity, which causes suspicion that the financing involved in it has been directly or indirectly acquired through a criminal activity or relate to terrorism and proliferation financing or attempt of such activity. In this case, a criterion to assess the reasonableness is based on subjective opinion - suspicion that might or might not arise, thus making the reporting duty subjective and such that can be interpreted widely according to each advocate's personal assuredness or understanding.

In the author's opinion, if a precise framework of criteria cannot be given, this widely and formally set duty to report about each suspicious action, oversteps the red lines guarding the advocate's immunity and the principle of proportionality. It is necessary to find a balance between these two dimensions of the nature of law, and it can be done by carrying out regular and consistent constitutional evaluation of authorities and persons involved in the application of law.

\section{R. Alexy considers that}

"[..] in ideal democracy, a democratic process will always show due respect to constitutional rights. In principle the conflict between democracy and constitutional rights will not exist. However, in real democracy the conflict exists. The reality of political life in joint connection with the idea about human rights and constitutional rights, however, require constant constitutional evaluation and revision." (Alexy, 2010, p.178).

It is necessary to revise the existing AMLFTP regulation by adjusting requirements in respect to advocate's activities as the subject of Law, possibly refuse from several of them because of their unenforceability due to limited resources, as well as the idea of assessments, based on subjective interpretation and to evaluate and listen to the assessments of specialists of advocacy and analysis about the advocate's sector risk assessment (Sectoral risk assessment of the Latvian Sworn Advocates Collegiate, 2019) thus following the principle of sound legislation. 
Sandra Joksta. Challenge of Advocate's Profession in the Age of Money Laundering,

Terrorism Financing and Proliferation Evasion "Not to slip with a fragile burden!"

\section{Conclusion}

Entitlement to professional secret and confidentiality form the basis of correct and just preparation for adjudgment of a case and simultaneously together with the advocate's independence - integral part of rights to fair trial by preserving the power of law and ensuring a just construction of democratic country. These rights are not only a privilege, but also an obligation and a precondition for establishment and functioning of correct legal system by allowing each party involved in the system to realise their rights.

With automatic invention of AML legislation into the national legislation in the advocate's sector, the advocate's immunity concept and the privilege adherent to it becomes more and more unclear.

The legislative enactment effective in the Republic of Latvian in the area of AML is systemically contradictory with the Law of Advocacy and causes collision with other norms of higher legal rank - fundamental freedoms of individuals. There is a collision between the advocate's fundamental rights to professional secret and confidentiality and an obligation to report on a suspicious transaction, as well as with the client's legitimate trust as concerns confidentiality and loyalty to its representative, thus enforcing its fundamental right to fair trial and defence.

A reasonable compatibility or balance is required between the advocate's specific basic rights to professional secret and the legal regulations of AMLFTP. This balance can be achieved by using a risk-based approach in the analysis on the legislator's level in close and willing cooperation with specialists of respective sector.

\section{Bibliography}

1. Alexy, R. (2005). Balancing, Constitutional Review and Representation. International Journal of Constitutional Law. 3(4), 572-581. https://doi.org/10.1093/icon.moi040.

2. Alexy, R. (2010). The Dual Nature of Law. Ratio Juris, 23(2), 167-182. https://doi.org/10.1111/ j.1467-9337.2010.00449.x.

3. Apvienoto Nāciju Pamatprincipi par advokātu lomu. http://www.advokatura.lv/lv/dokumentipar-advokaturas-jautajumiem/radit/25.

4. Brief substantial description of the European Court of Human Rights judgement dated 19 November 2020 in the case "Klaus Mueller vs Germany" (application No. 24173/18) from the informative report of the Latvian Sworn Advocates Council on 26.10.2020.

5. Charter of core principles of the European Legal Profession and Code of Conduct for European Lawyers. http://www.ccbe.eu/fileadmin/userupload/NTCdocument/EN_CCBE_ CoCpdf1_1382973057 pdf.

6. Charter of the collegium of the Latvian sworn advocates. (1993). Adopted at General meeting of sworn advocates in May 21, 1993. https://advokatura.lv/lv/dokumenti-par_advokaturas-jautajumiem/radit/232.

7. Code of ethics of the Latvian sworn advocates. (1993). Adopted at General meeting of sworn advocates in May 21, 1993. https://advokatura.lv/lv/dokumenti-par_advokaturas-jautajumiem/ radit/23 
Sandra Joksta. Challenge of Advocate's Profession in the Age of Money Laundering,

Terrorism Financing and Proliferation Evasion "Not to slip with a fragile burden!"

8. European Court of Human Rights Judgment in the case "Klaus Mueller v Germany" (2020) (application No. 24173/18). http://hudoc.echr.coe.int/eng?i=001-206165.

9. International Treaty: The Convention for the Protection of Human Rights and Fundamental Freedoms. (1997). Latvijas Vēstnesis, No. 14/44. https://likumi.lv/ta/lv/starptautiskie-ligumi/ $\mathrm{id} / 649$.

10. Law of the Republic of Latvia: The law on combating money laundering and the financing of terrorism and proliferation. (2008). https://likumi.lv/ta/id/178987.

11. Law of the Republic of Latvia: Advocacy Law of the Republic of Latvia. (1993). https://likumi. $\mathrm{lv} / \mathrm{ta} / \mathrm{id} / 59283$.

12. Plevako, F. N. (2017). Izbrannye rechi. Moskva: Jurait.

13. Sectoral risk assessment of the Latvian Sworn Advocates Collegiate (2019) prepared according to the World Bank methodology suggested by the Financial Intelligence Service. https://www. advokatura.lv/lv/nilltpfnl-sl-jautajumi/zverinatu-advokatu-nilltpf-risku-novertejums/.

14. US Supreme Court case “Upjohn Company v. United States", 449 U.S. 383, 393, 101 S. Ct. 677 (1981).

15. Zemribo, G. (2011). Kāds ir zvērināta advokāta statuss: Tiesu sistēmai piederīga amatpersona vai brīvā profesija [What is the status of a sworn advocate]. Jurista Vārds, 19 (666). https:// juristavards.lv/doc/229706-kads-ir-zverinata-advokata-statuss/.

16. Zemribo, G. (2011). Tiesu sistēmai piederīga amatpersona vai brīvā profesija [Official of the judiciary or liberal profession]. Delfi. https://www.delfi.lv/news/comment/comment/gvido-zemribotiesu-sistēmai-piederiga-amatpersonaivai-briva-profesija. 